\title{
||||||||||||||||||||||||
}

\section{「省エネ・節電に挑むソフトコンピューティング」 特集にあたって}

\section{日本知能情報ファジィ学会会誌編集委員会}

環境問題や, 東日本大震災の影響による電力不足な どにより, 省エネ・節電がオフィス, 工場, 大学, 公 共スペース, さらには個々の家庭レベルで要求されて いる，消費電力を抑えるためには，空調や生産設備な ぞを効率よく稼働させるための知的制御，機器の状態 や，対象とする環境を正しく把握するためのモニタリ ングに関する技術が重要となる。また，家庭やオフィ スなど住環境での省エネ・節電を考えた場合，住人な どのライフスタイルを考慮した省エネ・節電対策の検 討や，快適性を損なわない範囲での省エネ・節電対策 の実施が必要であり, 感性や主観と言った人間中心の システム構築が重要となる。

これら省エネ・節電に関する要素技術は全て, 本学 会と関連の深いものであることがわかる，すでに応用 され，成果を上げている技術もあれば，新たな技術の 研究開発が必要な課題もあると考えられる。本特集で は，省エネ・節電に関する現場で実際に活用されてい る, あるいは実用化に向けた研究開発が進められてい るソフトコンピューティング技術を紹介することを目 的として企画した。本特集は本会誌編集委員会がゲス トエディタとなり, 財団法人電力中央研究所, 株式会 社山武の方々に協力を依頼して, 省エネ・節電に関連 するソフトコンピューティング関連技術の応用事例に ついて紹介していただいた。解説は 6 編で，それぞれ 3 編ずつ執筆していただいた。おおまかな分類とし て, 電力中央研究所の方々には家庭を対象とした省工 ネ・節電, 山武の方々にはオフィスやプラント設備な どについてそれぞれ紹介していただいている。

前半 3 編の解説は, 電力中央研究所の方々によるも のである。上野氏の解説は, 居住者の選好を考慮し, 適切な省エネ行動の選択を支援するッールについての ものであり, 選好入力にAHP (Analytic Hierarchy Process) を利用している。 中野氏の解説は, 家庭内で 使用されている電気機器の運転状態を推定するため の，非侵襲なモニタリングに関するものであり，給電
線で観測される高調波成分に対しSVM(サポートベク ターマシン)などのパターン認識手法が用いられてい る. 所氏らの解説は, 家庭用ヒートポンプ式給湯機の 運転ルールに関するものであり, 多くの家庭で運転コ ストが小さくなる汎用運転ルールの生成方法について 説明している.

後半 3 編の解説は山武の方々によるものである. 綛 田氏の解説は, オフィスビル空調に打ける最新の省工 ネ技術について紹介して打り, 特にオフィスワーカー の温熱環境に対する満足感に着目した感性工学アプ ローチの重要性を指摘している. 笹岡氏の解説は, 設 備を安定稼働させることが事故対策だけでなく省エネ にもつながるとの立場から, ウェーブレット変換など を利用した設備状態の自動監視技術について紹介して いる. 鈴木氏の解説は, コジェネレーション設備, 圧 縮空気供給システムを対象として, 環境目標を実現す るための最適化技術, ツールについて紹介している.

本特集を企画したのは，2010年のことであり，京 都議定書への対応など, 環境問題に関連しての省エネ を想定していた。その後, 2011年 3 月に東日本大震 災が発生し, 環境問題対策のための省エネから, 電力 不足対策のための節電へと, 社会の視点・関心が遷移 している. 本学会が対象とする研究分野との関連だけ でなく, そのような状況の変化も踏まえて解説して頂 いた，執筆者の皆様にこの場を借りて謝意を表した い.

本特集で紹介した省エネ・節電に挑むアプローチを 大別すると，家庭を対象とした場合，オフィスやプラ ントを対象とした場合の双方に扔いて, 人間の感性・ 選好 (上野氏, 綛田氏), モニタリング (中野氏, 笹岡 氏), 知的制御(所氏ら, 鈴木氏) が挙げられる。これ らは全て, 本学会が対象とする研究領域に含まれるも のである. 本特集を契機として, 省エネ・節電に挑む ソフトコンピューティング技術が本学会から新たに生 まれることを期待したい. 